\title{
Faktor-Faktor yang Mempengaruhi Underprice Penawaran Saham Perdana di Indonesia
}

\author{
Hartanto \\ BINUS Entrepreneurship Center, Management Department, \\ Bina Nusantara University, \\ Jakarta, Indonesia, 11480 \\ hartanto@binus.ac.id
}

\begin{abstract}
The characteristics of an Initial Public Offering (IPO) is an important factor for several parties in achieving their goals, for example, for companies (which release the shares) will have a projection of the capital to be obtained, as well as for underwriters and investors to maximize their profits. Lack of knowledge of the character of the IPO, can cause problems, especially the potential loss to the several parties. This study aims to explore the character of IPO in Indonesia, especially the occurrence of Underprice and what are the factors that influence it. This study uses prospectus data of companies that conduct IPOs on the JSX, data library and websites that have the necessary data, the period 1995 to 2001. The results show that the Underprice phenomenon does indeed occur on IPOs on the JSX and most of the variables tested have an influence underprice occurrence. This study provides several suggestions including the need for the addition of more various variable.
\end{abstract}

Keywords - IPO; Underprice; Shares; Initial Stock Offer.

\begin{abstract}
ABSTRAK
Karakteristik Initial Public Offering (IPO) menjadi kunci penting bagi beberapa pihak dalam mencapai tujuan mereka misalnya bagi perusahaan (yang melepas saham) memiliki gambaran modal yang akan diperoleh, serta bagi underwriter dan investor untuk memaksimalkan keuntungan mereka. Kurangnya pengetahuan terhadap karakter IPO, dapat menimbulkan masalah terutama potensi kerugian bagi pihak yang berkepentingan. Penelitian ini bertujuan untuk menggali karakter IPO di Indonesia terutama terjadinya Underprice serta apa saja faktor yang mempengaruhinya. Penelitian ini menggunakan data prospektus perusahaan yang melakukan IPO di BEJ, data perpustakaan dan situs web yang memiliki data yang diperlukan, periode tahun 1995 sampai dengan 2001. Hasil penelitian menunjukkan bahwa fenomena Underprice memang terjadi pada IPO di BEJ dan sebagian besar variable yang diuji memiliki pengaruh terjadinya underprice. Penelitian ini memberikan sejumlah saran antara lain adalah perlunya penambahan variable yang lebih bervariasi.
\end{abstract}

Kata kunci - IPO; Underprice; Saham; Penawaran Saham Perdana.

\section{PENDAHULUAN}

Initial Public Offerings (IPO) memainkan peran yang penting bagi perusahaan guna memperoleh akses sumber daya finansial yang krusial dalam mengembangkan usaha. Namun demikian, disamping penting bagi perusahaan untuk menambah modal, disisi lain, pengetahuan tentang karakteristik IPO penting pula diketahui tidak hanya oleh manajer keuangan dan investor namun juga oleh underwriter agar dapat membantu masingmasing pihak menuju sasaran mereka.

Dalam penelitian ini penulis mencoba menggali fakta yang terjadi di lantai bursa khususnya di BEJ, tentang faktor-faktor yang mempengaruhi underprice suatu saham. Namun sebelum meneliti ke faktor-faktor yang 
menyebabkan underprice saham di BEJ, dalam tulisan ini terlebih dahulu penulis akan meneliti apakah terjadi underprice.

Dari beberapa penelitian terdahulu, terdapat bukti yang mengindikasikan bahwa perusahaan milik Pemerintah kurang efisien bila dibanding perusahaan swasta (Boardman\& Vining 1989). Kinerja pegawai pemerintah yang kurang efisien dan birokrasi yang berbelit melekat pada benak masyarakat dan investor. Sepanjang tahun 1995 hingga tahun 2001 di BEJ (Bursa Efek Jakarta) terdapat 3 badan usaha milik negara (BUMN) di Indonesia yang melakukan go public atau melepas saham yang dimiliki pemerintah melalui Initial Public Offering (IPO). Apakah indikasi kinerja BUMN tersebut mempengaruhi underprice saham mereka? Apakah perusahaan PMA memiliki potensi underprice lebih besar dibanding BUMN dan PMDN?

Disamping faktor kepemilikan perusahaan, faktor usia operasional perusahaan (dihitung sejak perusahaan berdiri hingga perusahaan melakukan go public) penting untuk diketahui hubungannya dengan underprice saham. Dalam penelitian sebelumnya yang pernah dilakukan, terbukti usia perusahaan memiliki hubungan negatif signifikan dengan initial return (Muscarella \& Vetsuypens 1987). Semakin tua usia perusahaan, maka initial return akan semakin kecil. Sebaliknya bila usia perusahaan masih muda, maka initial return akan lebih tinggi. Namun Carter (1987), meneliti bahwa terdapat hubungan positif signifikan antara underpricing dengan usia perusahaan. Semakin tua usia perusahaan maka semakin tinggi initial return, dan sebaliknya bila usia perusahaan masih muda maka initial return akan lebih rendah dari usia perusahaan yang lebih tua.

Kategori industri perusahaan juga merupakan faktor penting yang perlu diperhatikan dalam hubungannya dengan derajat underprice suatu saham. Dalam suatu journal yang meneliti hubungan antara kategori industri dan underprice harga saham, terbukti kategori industri mempengaruhi tinggi/rendahnya derajat underprice suatu saham. Ritter (1984) menegaskan perusahaan di suatu industri dapat memiliki derajat underprice yang lebih tinggi dibanding perusahaan di industri yang berbeda.

Disamping faktor diatas, tahun pelaksanaan IPO juga memiliki faktor yang tidak kalah penting dalam mempengaruhi derajat underprice suatu saham. Menurut penelitian yang dilakukan oleh Ibbotson \& Jaffe (1975), underprice merupakan fenomena berulang (cyclical phenomenon) yang terjadi dari suatu tahun ke tahun berikutnya, ditandai dengan periode dimana derajat underprice tinggi ("Hot Issue" market) pada suatu periode, kemudian diikuti dengan periode dimana derajat underprice rendah ("Cold Issue" market) pada periode berikutnya.

Penelitian ini memfokuskan pada dua hal penting menyangkut IPO di Indonesia meliputi:

1. Apakah IPO masih layak dijadikan ajang mencari keuntungan oleh investor? Akan diuji dengan melihat apakah terjadi abnormal return dari saham perdana yang ditandai dengan terjadinya underprice penjualan saham hari pertama di BEJ?

2. Variabel-variabel apa saja yang mempengaruhi terjadinya underprice pada penawaran saham perdana?

Dalam penelitian ini penulis menggunakan data harga saham perusahaan-perusahaan yang melakukan IPO (Initial Public Offering) yang terdapat di BEJ (Bursa Efek Jakarta) periode tahun 1995 hingga tahun 2001. Data saham menggunakan 92 (sembilan puluh dua) harga saham perdana dari 9 (sembilan) industri yang berbeda. Data digunakan untuk menganalisa underprice saham di BEJ dan variabel-variabel yang mempengaruhinya.

\section{METODE PENELITIAN}

Data yang digunakan merupakan data sekunder yang diambil dari prospektus perusahaan yang melakukan IPO di BEJ. Disamping itu penelitian ini juga menggunakan data perpustakaan dan beberapa situs web site yang mempunyai data yang diperlukan.

Pemilihan sampel dalam penelitian ini dilakukan dengan menggunakan metode purposive sampling, dengan kriteria emiten yang melakukan pencatatan (listing) serta melakukan penawaran saham perdana di BEJ periode tahun 1995 sampai dengan 2001.

Sampel yang diambil diharapkan bisa mewakili keseluruhan populasi yang merupakan seluruh emiten yang akan melakukan listing perdana serta melakukan penawaran di BEJ.

Penelitian karakter saham underpricing ini, dilakukan menggunakan data sekunder yang didapat dari: 
1. Indonesian Capital Market Directory 2000, edisi 11 yang dikeluarkan oleh Institute for Economic and Financial Research (ECFIN) - Jakarta.

2. Indonesian Capital Market Directory 2002, edisi 13 yang dikeluarkan oleh Institute for Economic and Financial Research (ECFIN) - Jakarta.

3. Data-data saham Indo Camary periode tahun $1995 \mathrm{~s} / \mathrm{d}$ tahun 2001 yang dikelola oleh MM-UGM Jakarta.

4. Data-data saham dari web site http://www.jsx.co.id yang merupakan situs Jakarta Stock Exchange (Bursa Efek Jakarta).

Jenis data yang digunakan dalam penelitian adalah:

1. Harga penawaran saham (offering price), merupakan harga perdana saham yang ditawarkan pada saat Initial Public Offering dilakukan.

2. Harga penutupan saham hari pertama (first day closing price), yaitu harga saham pada penutupan perdagangan di hari pertama saham tersebut masuk bursa.

3. Market Capitalization, kapitalisasi pasar yaitu jumlah saham dalam lembar yang dijual dikali harga saham perlembar.

4. Kategori Industri, merupakan kategori saham perusahaan menurut industri yang ditetapkan BEJ (Bursa Efek Jakarta).

5. Tahun IPO, tahun pelaksanaan penjualan perdana saham perusahaan yang go public melalui Initial Public Offering (IPO).

6. Jumlah pegawai, merupakan jumlah pegawai perusahaan yang akan melakukan go public. Data pegawai diambil dari prospectus pada saat perusahaan akan melakukan IPO.

7. Kepemilikan, merupakan kepemilikan awal perusahaan sebelum go public terdiri dari perusahaan BUMN, PMDN dan PMA. Data kepemilikan diambil dari prospectus pada saat perusahaan akan melakukan IPO.

8. Usia perusahaan, merupakan tahun historis sejak perusahaan pertama kali beroperasi hingga saat melakukan IPO. Data usia perusahaan diambil dari web site: http://www.jsx.co.id.

9. Initial return, merupakan return suatu saham yang didapat pada hari pertama perdagangan, yaitu: harga saham pada penutupan perdagangan hari pertama dikurangi harga saham perdana dibagi harga saham perdana.

10. Underwriter, merupakan pihak pencatat saham yang dikeluarkan oleh emiten pada perdagangan saham hari pertama.

Sampel yang digunakan pada penelitian ini dipilih menggunakan purposive sampling. Data yang digunakan merupakan saham perusahaan yang melakukan Initial Public Offering pada periode tahun 1995 sampai dengan tahun 2001 di BEJ. Jumlah saham yang melakukan IPO yang diambil pada periode tersebut sebanyak 92 saham. Jumlah sampel saham digunakan dalam rentang waktu yang panjang ( 7 tahun) untuk dapat melihat lebih tepat trend underprice saham IPO di BEJ. Sampel saham yang digunakan per tahun adalah sebagai berikut:

Tabel 1. Sampel Saham Yang Digunakan Per Tahun

\begin{tabular}{ccc}
\hline No. & Tahun & Jumlah Saham \\
\hline 1 & 1995 & 15 \\
2 & 1996 & 3 \\
3 & 1997 & 6 \\
4 & 1998 & 6 \\
5 & 1999 & 21 \\
6 & 2000 & 28 \\
7 & 2001 & 92 \\
\hline
\end{tabular}


Kriteria-kriteria yang dipakai dalam pemilihan sampel penelitian ini adalah sebagai berikut:

1. Perusahaan yang tercatat dan menjual saham mereka pada publik di BEJ. Dari pengamatan kami ada tiga perusahaan yang listing di BEJ namun sahamnya tidak dijual kepada publik yaitu:

1. PT. Ciputra Surya Tbk.

2. PT. Samudra Indonesia Tbk.

3. PT. Jaka Artha Graha Tbk.

Ketiganya tidak dimasukkan kedalam penelitian ini.

2. Perusahaan yang memiliki data variabel dengan lengkap. Variabel dimaksud meliputi:

1. Underwriter yang melakukan pencatatan di BEJ.

2. Tahun dilaksanakannya IPO.

3. Usia operasional perusahaan.

4. Kategori industri perusahaan di BEJ.

5. Jumlah pegawai saat IPO.

6. Harga penawaran perdana saham.

7. Market kapitalisasi saham dan

8. Kepemilikan awal perusahaan sebelum IPO. berikut:

Variabel-variabel yang digunakan dari sample saham sesuai prospectus yang telah ditentukan sebagai

\section{Reputasi Underwriter (UW)}

Tingkat reputasi underwriter didasarkan pada peringkat yang dibuat oleh majalah Bursa dan Efek (1997), yang didasarkan pada nilai IPO. Emiten yang menggunakan underwriter dengan persentase terhadap total nilai IPO di atas 3\% diberi kode 1 dan apabila menggunakan underwriter lainnya menggunakan kode 0 . Underwriter yang mempunyai persentase di atas $3 \%$ tersebut adalah,

1. Danareksa

2. Bahana Securities

3. Makindo

4. Ficorinvest

5. Lippo Securities

6. WI Carr Indonesia

7. Bapindo

8. Jardine Fleming Nusantara

\section{Harga penawaran saham (offering price)}

Harga penawaran saham (offering price) merupakan harga perdana saat saham pertama kali masuk bursa. Harga penawaran ini diperoleh dari Prospectus yang disampaikan oleh emiten pada saat IPO saham perdana. Data dalam satuan rupiah dan dilakukan log pada data untuk menstandarisasi data.

\section{Usia Operasional perusahaan}

Usia operasional perusahaan merupakan usia yang dihitung sejak perusahaan berdiri hingga perusahaan masuk bursa / melaksanakan IPO saham perdana. Data diperoleh dari website resmi BEJ. Data dalam tahun dan dilakukan log pada data untuk menstandarisasi data.

\section{Kategori Industri}

Kategori industri merupakan pengelompokkan jenis saham perusahaan menurut jenis industrinya di Bursa Efek Jakarta. Ada 9 (sembilan) kategori industri yang terdapat di BEJ. Dalam penelitian ini penulis mengkasifikasi industri dalam dua kategori yakni: keuangan dan non keuangan. Untuk kategori non keuangan menggunakan nilai dummy 1 dalam perhitungan statistik (karena dianggap rendah resiko) dan kategori keuangan menggunakan nilai dummy 0 (karena beresiko tinggi) untuk perhitungan statistik. 


\section{Tahun IPO}

Tahun IPO merupakan tahun pelaksanaan IPO saham perdana yang dilakukan oleh suatu emiten. Sesuai batasan penelitian, tahun IPO dibatasi periode tahun 1995 hingga tahun 2001. Data dalam tahun dan dilakukan log pada data untuk menstandarisasi data.

\section{Size Company}

Size company diproxykan oleh dua variabel yaitu: jumlah pegawai dan market capitalization. Jumlah pegawai menggunakan data jumlah pegawai saat perusahaan melakukan IPO saham perdana. Data diambil dari prospektus yang dikeluarkan oleh emiten sebelum IPO dilakukan. Data dalam jiwa, dan dilakukan log pada data untuk menstandarisasi data.

Sedangkan kapitalisasi pasar (market capitalization) merupakan hasil perkalian jumlah saham yang ditawarkan (dalam lembar) dengan harga penawaran (offering price). Data dalam Rupiah dan dilakukan log pada data untuk menstandarisasi data.

Rumus 1. Formula Kapitalisasi Pasar

$$
\text { Kapitalisasi pasar (Rp.) = Jml saham ditawarkan (lbr) x harga penawaran (Rp.) }
$$

\section{Kepemilikan perusahaan}

Kepemilikan awal perusahaan sebelum IPO terdiri dari dua kategori yakni: PMA dan BUMN-PMDN. Untuk perhitungan statistik kepemilikan perusahaan juga menggunakan nilai dummy, nilai 0 untuk PMA karena dianggap lebih beresiko dan nilai 1 untuk BUMN-PMDN karena memiliki resiko lebih rendah.

\section{METODE PENELITIAN}

\section{Metode Analisis Data}

Metode yang dilakukan untuk melakukan analisa data adalah membentuk pola penelitian antara lain menghitung abnormal return dan membuktikan terjadi underprice, kemudian melakukan analisis regresi untuk melihat pengaruh yang ditimbulkan dari tiap-tiap variabel terhadap underprice saham perdana.

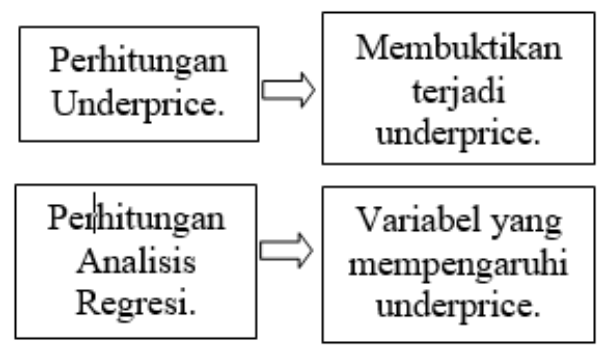

Gambar 1. Metode Analisis Data

\section{Perhitungan Underprice}

Pada saham perdana, initial return dapat digolongkan sebagai return tidak normal atau Abnormal Return. Derajat underprice dapat dihitung melalui initial return suatu IPO berupa selisih offer price ( $\mathrm{P}_{0}$, harga penawaran) dan harga penutupan pada perdagangan hari perdana saham di pasar sekunder $\left(\mathrm{P}_{1}\right)$, kemudian dibagi dengan harga penawaran $\left(\mathrm{P}_{0}\right)$ untuk memperoleh underprice.

Berikut rumus yang digunakan untuk mengukur derajat underprice saham menurut Fernandez 1993:

Rumus 2. Formula Underprice

$$
\stackrel{\%}{\text { underprice }}=\frac{\mathrm{P}_{1}-\mathrm{P}_{0}}{\mathrm{P}_{0}}
$$


$\mathrm{P}_{0}=$ Harga penawaran saham

$\mathrm{P}_{1}=$ Harga saham pada perdagangan perdana di pasar sekunder.

Untuk menguji signifikansi dari underprice saham yang terjadi, dilakukan analisis menggunakan mean dan analisis uji $\mathrm{t}$ (student $\mathrm{t}$ test) dengan persamaan sebagai berikut:

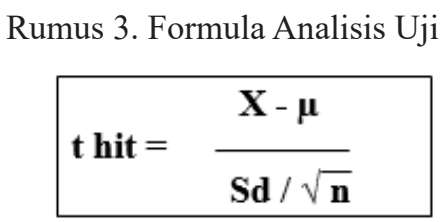

t hit $=$ Besarnya t hitung

$\mathrm{X}$ = Rata-rata

$\mu \quad=$ Parameter hipotesis

$\mathrm{Sd}=$ Standar Deviasi

$\mathrm{n} \quad=$ Jumlah variable

Signifikansi yang dimaksud dengan uji mean adalah bahwa abnormal return tersebut secara signifikan tidak sama dengan nol (yaitu bernilai positif untuk underprice dan negatif untuk overprice).

Tingkat taraf nyata $(\alpha)$ sebesar 0,05 dengan derajat kebebasan (degree of freedom) sebesar n-1. Uji t (student-t test) akan menunjukkan hasil bahwa abnormal return bersifat signifikan bila $t$ hitung $>t$ variable (one tail) serta $t$ hitung $>$ t variable ; $-\mathrm{t}$ hitung $<-t$ variable (two tail).

Perhitungan mean dan uji t, dilakukan menggunakan software SPSS 10.0 untuk mempermudah perhitungannya.

\section{Analisis Linier Regresi Berganda.}

Korelasi yang terjadi antara variabel underprice saham (sebagai dependent variabel) dengan variabelvariabel lain yang diuji (sebagai independent variabel), akan diuji menggunakan model regresi linear full cross sectional.

Model pengujian sebagai berikut:

Rumus 4. Formula Model Regresi Linear Full Cross Sectional

$$
\mathrm{UND}=\mathrm{b} 0+\mathrm{bl}(\mathrm{UW})+\mathrm{b} 2(\text { Ofprice })+\mathrm{b} 3(\text { Age })+\mathrm{b} 4(\mathrm{Ind})+\mathrm{b} 5(\mathrm{Thn})+\mathrm{b} 6(\text { Size })+\mathrm{b} 7 \text { (Owner) }
$$

\section{Keterangan:}

Und $\quad=$ Underprice saham perdagangan hari pertama.

b0 $\quad=$ konstanta

$\mathrm{b} 1 \mathrm{~s} / \mathrm{d} \mathrm{b} 7=$ koefisien regresi variabel independen

UW $\quad=$ Prestige underwriter, dummy 0 less prestige dan 1 more prestigious.

Ofprice $\quad=$ Offering price, harga penawaran perdana saham IPO.

Age $\quad=$ Usia operasional perusahaan.

Ind $\quad=$ Kategori industri, dummy 0 untuk keuangan, 1 untuk non keuangan.

Thn $\quad=$ Tahun pelaksanaan IPO.

Size $\quad=$ Ukuran perusahaan, diproxykan jumlah pegawai dan market cap.

Owner $\quad=$ Pemilik mayoritas perusahaan sebelum IPO, bernilai dummy 0 untuk PMA dan 1 untuk BUMNPMDN. 
Untuk menguji hipotesa yang telah diformulasikan, akan dilakukan uji statistik berikut:

1. Uji parsial koefisien regresi menggunakan t-test untuk menguji signifikansi pengaruh variabel independen terhadap variabel dependen.

2. Uji R-square untuk mengetahui berapa besar variabel independen dapat menjelaskan variabel dependen (dalam persentase).

3. Uji signifikansi keseluruhan koefisien independen secara bersama-sama terhadap variabel dependen dengan menggunakan F-test.

4. Uji multikolinearitas antara variabel independen.

\section{Hipotesa}

\section{Underprice dan Initial Return}

Perusahaan yang untuk pertama kalinya melepas sahamnya ke pasar sekunder saham disebut melakukan penawaran saham perdana (initial public offering atau IPO). Underwriter yang menjamin pelemparan saham perdana akan menanggung risiko untuk menjual saham ini disebabkan nilai pasar dari sekuritas belum diketahui. Oleh karena itu, underwriter cenderung untuk menjualkannya dengan harga yang murah (underprice) agar mengurangi risiko tidak laku terjual (Hartono, 2000). Investor yang mendapat kesempatan untuk membeli sekuritas yang undervalued ini akan dapat menikmati abnormal return.

Derajat underprice/overprice dapat dihitung dari initial return suatu IPO, dimana perbedaan antara offer price $\left(\mathrm{P}_{0}\right.$, harga penawaran) dan harga pada perdagangan saham perdana di pasar sekunder $\left(\mathrm{P}_{1}\right)$ dibagi dengan harga penawaran $\left(\mathrm{P}_{0}\right)$. Berikut rumus yang digunakan untuk mengukur derajat underprice suatu saham menurut Fernandez 1993.

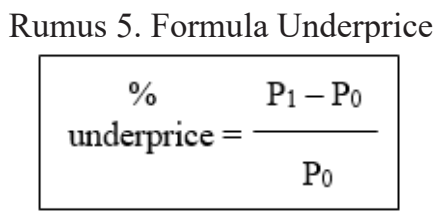

$\mathrm{P}_{0}=$ Harga penawaran saham.

$\mathrm{P}_{1}=$ Harga saham pada perdagangan perdana di pasar sekunder.

Underprice terjadi ketika $\mathrm{P}_{1}$ lebih tinggi daripada $\mathrm{P}_{0}$. Sedangkan Overprice terjadi ketika $\mathrm{P}_{1}$ lebih rendah daripada $\mathrm{P}_{0}$. Selisih antara harga penawaran dan harga perdagangan perdana $\left(\mathrm{P}_{0}\right.$ dan $\left.\mathrm{P}_{1}\right)$ disebut initial return. Oleh karena itu, dalam penelitian ini penulis terlebih dahulu akan mengukur tingkat underprice saham perdana yang tidak lain adalah abnormal return (return tidak normal) pada saham perdana IPO.

Pada analisa ini, penulis menggunakan hipotesis:

H1: Terjadi fenomena underprice pada saham saat penawaran perdana di BEJ.

\section{Variabel-variabel yang mempengaruhi Underprice Saham IPO}

Studi-studi yang telah dilakukan sebelumnya, terutama yang mengkaji potensial profit bagi investor, seperti pada Brown (1970), McDonald \&Fisher (1973) dan Block \& Stanley (1980) menemukan hasil studi yang konsisten bahwa IPO rata-rata selalu mengalami underprice. Menurut Ritter (1998) terdapat sejumlah alasan yang melatarbelakangi saham baru mengalami underpricing. Dari beberapa teori berbeda, umumnya teori-teori tersebut berfokus pada aspek-aspek hubungan antara investor, issuers (emiten), dan underwriter.

Menurut teori Rock (1986) IPO harus underprice dengan tujuan menghasilkan return bagi investor tanpa informasi, sehingga mereka akan terus berpartisipasi pada pasar IPO. Bila proses IPO diasumsi mengalami underprice, baik investor yang terinformasi maupun investor yang tidak terinformasi keduanya akan melakukan bid (penawaran pembelian). Investor yang tidak terinformasi akan melakukan penawaran pembelian dengan jumlah acak, hal ini mengingat mereka tidak memiliki akses dan biaya yang memadai untuk mengetahui harga saham sebenarnya. Karena jumlah penawaran pembelian yang berlebih dari para investor maka perlu diadakan penjatahan dalam pembelian. Investor yang memiliki informasi tidak akan menambah jumlah penawaran pembelian mereka saat itu karena mereka telah memiliki perkiraan harga saham yang akan dilepas. Sedangkan 
investor yang tidak memiliki informasi akan menambah penawaran pembelian dimana mereka memiliki resiko untuk menerima harga dengan overprice.

Selain penelitian di luar negeri, terdapat pula penelitian-penelitian tentang emisi perdana di Indonesia. Kebanyakan penelitian tersebut tentang signal-signal yang mempengaruhi tingkat underpricing. Signal-signal tersebut antara lain reputasi underwriter dan auditor, persentase saham yang ditawarkan oleh publik, tingkat profitabilitas emiten, dan tingkat leverage. Selanjutnya variabel-variabel yang akan diuji dalam penelitian ini adalah:

\section{Prestige Underwriter terhadap underprice saham}

Beberapa peneliti yang khusus melakukan studi tentang underpricing menyatakan berdasarkan kelaziman, para penulis telah mengidentifikasi faktor-faktor atau karakteristik yang menjelaskan derajat underprice suatu saham. Logue (1973), Block \& Stanley (1980) dan Tinic (1988) menemukan hubungan terbalik antara prestige (nama) dari underwriter dengan initial return pada saat IPO. Sedangkan penelitian lain, Carter (1987) menemukan hal bahwa prestige underwriter memiliki hubungan positif yang signifikan terhadap underprice. Fernandez 1993 menyatakan underwriter memiliki hubungan negatif signifikan dengan underprice suatu saham. Perhitungan yang dilakukan oleh Fernandez 1993, underprice yang lebih tinggi justru diperoleh dari underwriter yang memiliki prestise lebih rendah. Perbedaannya tampak sekitar $2 \%$ antara underprice dari underwriter more prestigious dibanding underwriter yang less prestigious.

Dalyono (2000), dengan data emisi perdana dari tahun 1990-1997, menemukan bahwa hanya variable reputasi underwriter dan leverage emiten saja yang mempengaruhi tingkat underpricing.

Nasirwan (2000) mengembangkan penelitian dengan mengganti tingkat underpricing dengan return saham 15 hari dan setahun setelah listing perdana. Hasilnya menunjukkan bahwa reputasi underwriter dan resiko saham berhubungan positif yang signifikan dengan return saham 15 hari sesudah listing, sedangkan persentase saham publik dan harga saham perdana berhubungan negatif secara signifikan.

Dari teori-teori yang disampaikan diatas maka hipotesis yang digunakan adalah:

H2 : Nama baik underwriter berpengaruh terhadap terjadinya underprice saham perdana di BEJ.

\section{Harga penawaran saham (offering price) terhadap underprice saham}

Tinic (1988) menyatakan bahwa harga penawaran saham yang rendah cenderung diterbitkan oleh perusahaan yang memiliki faktor spekulatif tinggi. Studi empiric dari pernyataan ini menurut Tinic (1988) dibuat oleh Osborne (1969) yang menyatakan bahwa harga penawaran saham yang rendah akan mudah naik dibanding harga penawaran saham yang tinggi.

Namun pada Fernandez (1993) saham-saham baru di Spanyol memiliki return yang lebih tinggi pada tahun 1988 sampai tahun 1989, dan return lebih rendah pada tahun 1987 dan 1990. Nampak bahwa pada tahun 1988 dan tahun 1989 karakteristik IPO yang terjadi adalah jumlah saham yang besar dan jumlah market kapitalisasi yang lebih besar dibanding tahun-tahun lainnya.

Pada variabel ini hipotesis yang digunakan adalah:

H3 : Harga penawaran saham memiliki pengaruh positif pada underprice saham perdana.

\section{Usia Operasional perusahaan terhadap underprice saham}

Muscarella \& Vetsuypens (1987) menemukan hubungan negatif yang signifikan antara underprice dan usia perusahaan. Sedangkan yang lain, Carter (1987) menemukan hal bahwa usia perusahaan dan demikian juga prestige nama underwriter memiliki hubungan positif yang signifikan terhadap underprice.

Penelitian Fernandez 1993 mengungkapkan tidak adanya hubungan antara umur perusahaan dan derajat underpricing ketika go public. Didalam kasus ini, hubungan yang terjadi lemah dan tidak signifikan secara statistik.

Umur perusahaan menggunakan ukuran beroperasi perusahaan secara historis. Hal ini dianggap juga suatu proxy atas ketersediaan informasi atas perusahaan [Barry\& Brown (1985)]. Pengaruh umur terhadap penerbitan saham baru pada investor tidak signifikan. Usia operasional perusahaan memiliki pengaruh positif terhadap underprice.

Carter (1987), meneliti bahwa terdapat hubungan positif signifikan antara underpricing dengan usia perusahaan. Semakin tua usia perusahaan maka semakin tinggi underprice, dan sebaliknya bila usia perusahaan 
masih muda maka underprice akan lebih rendah dari usia perusahaan yang lebih tua. Trisnawati (1998), dengan data emisi saham dari tahun 1994-1995, menemukan bahwa umur perusahaan merupakan signal positif yang signifikan, sedangkan reputasi auditor bukan signal yang signifikan terhadap tingkat underpricing.

Pada variabel ini hipotesis yang digunakan adalah:

H4 : Usia perusahaan berpengaruh terhadap terjadinya underprice saham perdana di BEJ.

\section{Kategori Industri terhadap underprice saham}

Ritter (1984) mendapatkan bahwa perusahaan-perusahaan yang ada pada salah satu kategori industri, dimungkinkan untuk memiliki derajat underprice yang lebih tinggi dibanding dengan perusahaan-perusahaan pada kategori yang berbeda. Dengan kata lain, derajat underprice setiap perusahaan bisa berbeda berdasarkan kategori industri perusahaan tersebut di pasar bursa.

Fernandez 1993 menyatakan bahwa terdapat perbedaan pada mean dari underprice diantara kategori industri. Salah satu penjelasan untuk perbedaan underprice diantara kategori industri yang mencerminkan derajat underprice adalah bahwa kategori perusahaan yang memiliki derajat underprice tinggi adalah kategori industri yang memiliki resiko tinggi dari kategori industri lainnya, contohnya perusahaan pada kategori Energy dan Chemical industri.

Lebih dari itu, derajat underpricing industri tertentu dipengaruhi oleh apakah industri tersebut sering atau hanya jarang masuk pada pasar bursa. Industri dengan kapitalisasi pasar lebih tinggi dan menyebabkan beban lebih besar di dalam keseluruhan pencapaian pasar mungkin memiliki derajat underpricing lebih rendah. Hal ini terutama sebagian besar disebabkan investor dalam beberapa industri mempunyai akses lebih informasi sehingga memiliki data acuan untuk menilai penetapan harga saham baru. Posisi relatif perusahaan dalam industrinya adalah hal lain yang menentukan faktor derajat underpricing. Perusahaan yang memimpin di industri mereka akan lebih menarik bagi investor dan karena itu mengalami derajat underpricing yang lebih rendah, seperti pada industri transportasi dan industri komunikasi.

Pada variabel ini hipotesis yang digunakan adalah:

H5 : Kategori industri memiliki pengaruh positif pada underprice saham perdana.

\section{Tahun Pelaksanaan IPO terhadap underprice saham}

Penelitian yang dilakukan oleh Ibbotson dan Jaffe (1975), menemukan bahwa underprice suatu saham yang baru dilepas saat IPO tidak lain merupakan suatu hal cyclical phenomenon (fenomena yang berulang) yang terjadi pada karakteristik periode dengan high underprice ("Hot Issue" market) yang kemudian diikuti oleh suatu periode dengan low underprice ("Cold Issue" market).

Fernandez 1993 pada penelitian yang dilakukannya mendapatkan bahwa terdapat perbedaan signifikan antara derajat underprice pada tahun 1987 dan 1990 di Spanyol dengan tahun-tahun lainnya. Dimana pada kedua tahun tersebut underprice mencapai tingkat terendah, hingga mencapai titik negatif. Sedangkan bila dilihat tahuntahun lainnya semuanya menunjukkan percentase positif.

Pada variabel ini hipotesis yang digunakan adalah:

H6 : Tahun pelaksanaan IPO berpengaruh terhadap terjadinya underprice saham perdana di BEJ.

\section{Size Company terhadap underprice saham}

Fernandez 1993 melakukan pengujian variabel-variabel yang mempengaruhi derajat underprice saham perdana di Spanyol. Dalam penelitian yang mereka lakukan, penjualan (sales), jumlah karyawan, dan kapitalisasi pasar digunakan sebagai wakil untuk menghitung efek ukuran perusahaan. Dalam penelitian Fernandez (1993) mereka mendapatkan bahwa ketiganya berpengaruh negatif dalam tingkat underprice penawaran saham perdana.

Pada variabel ini hipotesis yang digunakan adalah:

H7 : Size perusahaan berpengaruh terhadap terjadinya underprice saham perdana di BEJ.

\section{Kepemilikan perusahaan terhadap underprice saham}

Kepemilikan awal perusahaan sebelum IPO juga menarik untuk disimak, apakah terjadi perbedaan underprice yang signifikan antara perusahaan milik asing, dalam hal ini perusahaan berstatus PMA (penanaman modal asing), dengan perusahaan yang berstatus BUMN (badan usaha milik negara) dan PMDN (penanaman modal dalam negeri). 
Pada variabel ini hipotesis yang digunakan adalah:

H8 : Kepemilikan perusahaan awal memiliki pengaruh positif pada terjadinya underprice saham perdana di BEJ.

\section{HASIL DAN PEMBAHASAN}

\section{Initial Return dan Underprice saham IPO}

Dari perhitungan yang dilakukan dengan menggunakan program excell dan SPSS berikut adalah hasil perhitungan initial return 92 saham sepanjang tahun 1995 hingga 2001:

Tabel 2. Hasil Perhitungan Underprice Saham

\begin{tabular}{cccc}
\hline Total Saham Diteliti & Underprice & Tetap & Overprice \\
\hline 92 saham & 78 saham & 5 saham & 9 saham \\
$(100 \%)$ & $(85 \%)$ & $(5 \%)$ & $(10 \%)$ \\
\hline
\end{tabular}

Dari 92 saham yang dihitung initial returnnya, sebanyak 9 saham diantaranya mengalami overprice yang ditandai dengan initial return yang negatif. Disamping itu, terdapat 5 saham yang mengalami initial return sama dengan 0 , atau dengan kata lain, harga penawaran saham sama dengan harga penutupan pada hari pertama perdagangan dilantai bursa. Selebihnya, sebanyak 78 saham mengalami underprice, yang ditandai dengan initial return yang positif.

Tabel 3. Hasil Perhitungan T-Test

\begin{tabular}{cccc}
\hline Mean & St Dev & t-statistic & Sig. \\
\hline 0.89342 & 1.35539 & 6.32244 & 0,000 \\
\hline
\end{tabular}

Dari perhitungan statistik nampak bahwa rata-rata underprice saham perdana sejak tahun 1995 hingga 2001 adalah sebesar 0,89342 atau sebesar 89,342\% tiap IPO saham, dengan standar deviasi sebesar 1,35539 atau sebesar $135,539 \%$.

\section{Analisis Variabel}

Selanjutnya dilakukan pengujian variabel-variabel yang diduga mempengaruhi underprice saham IPO di BEJ. Teknik analisa yang digunakan dalam penelitian ini adalah regresi linier berganda yang dilakukan dengan menggunakan software program SPSS 10.0.

Pengujian dilakukan dengan memasukkan semua variabel, baik variabel independen maupun dependen, antara lain: underprice, underwriter, tahun IPO, usia operasional, industri, offering price, jumlah pegawai, market kapitalisasi dan kepemilikan.

Data selengkapnya berkenaan variabel yang dihitung dapat dilihat pada bagian lampiran penelitian ini. Hasil perhitungan statistik analisis regresi dari software SPSS 10.0 adalah sebagai berikut:

Tabel 4. Hasil Perhitungan Regression Analysis

\begin{tabular}{cccccc}
\hline & $\begin{array}{l}\text { Unstandardized } \\
\text { Coefficients }\end{array}$ & & $\begin{array}{l}\text { Standardized } \\
\text { Coefficients }\end{array}$ & $\mathrm{t}$ & Sig. \\
\hline B & Std. Error & Beta & & \\
\hline Constant) & $-1485,220$ & 1091,626 & & $-1,361$ & 0,177 \\
\hline INDUSTRI & 0,413 & 0,289 & 0,119 & 1,429 & 0,157 \\
\hline AGE & $-0,279$ & 0,171 & $-0,149$ & $-1,631$ & 0,107 \\
\hline EMPLOYEE & $-0,07697$ & 0,072 & $-0,103$ & $-1,069$ & 0,288 \\
\hline OWNER & $-0,603$ & 0,393 & $-0,119$ & $-1,532$ & 0,129 \\
\hline UW & 0,367 & 0,301 & 0,114 & 1,221 & 0,226 \\
\hline YEAR & 196,040 & 143,548 & 0,169 & 1,366 & 0,176 \\
\hline OFPRICE & $-0,574$ & 0,157 & $-0,519$ & $-3,663$ & 0,000 \\
\hline MCAP & 0,04164 & 0,100 & 0,036 & 0,417 & 0,678 \\
\hline a Dependent Variable: UND & & & &
\end{tabular}


Menurut tabel hasil perhitungan statistik diatas untuk underwriter, nampak bahwa nilai t-statistic untuk underwriter adalah 1,221. Nilai t-statistik tersebut lebih kecil dari t-tabel dengan alpha 5\% yaitu sebesar 1,99. Dan bila dihitung dari probabilitasnya, nilai signifikansi Underwriter pada tabel diatas adalah 0,226, nilai ini lebih besar dari nilai alpha 0,05 .

Tabel hasil perhitungan statistik juga menunjukkan bahwa nilai t-statistic untuk harga penawaran adalah $-3,663$. Nilai t-statistik tersebut lebih kecil dari t-tabel dengan alpha 5\% yaitu sebesar $-1,99$. Dan bila dilihat dari probabilitasnya, nilai signifikansi harga penawaran pada tabel diatas adalah 0 , nilai ini lebih kecil dari nilai alpha 0,05 .

Sedangkan nilai t-statistic untuk usia operasional adalah $-1,631$. Nilai t-statistik tersebut lebih besar dari t-tabel dengan alpha 5\% yaitu sebesar -1,99. Dan bila dilihat dari probabilitasnya, nilai signifikansi pada tabel diatas adalah 0,107 , nilai ini lebih besar dari nilai alpha 0,05 .

Nilai t-statistic untuk kategori industri adalah 1,429. Nilai t-statistik tersebut lebih kecil dari t-tabel dengan alpha 5\% yaitu sebesar 1,99. Sedangkan bila dilihat dari probabilitasnya, nilai signifikansi kategori industri pada tabel diatas adalah 0,157 , nilai ini lebih besar dari nilai alpha 0,05 .

Tabel analisis regresi diatas juga menunjukkan bahwa nilai t-statistic untuk Tahun IPO adalah 1,366. Nilai t-statistik tersebut lebih kecil dari t-tabel dengan alpha 5\% yaitu sebesar 1,99. Dan dari probabilitasnya, nilai signifikansi tahun IPO pada tabel diatas adalah 0,176 , nilai ini lebih besar dari nilai alpha 0,05 .

Size perusahaan diproxykan oleh dua variabel independen yaitu jumlah pegawai dan market kapitalisasi. Pada tabel statistik analisis regresi diatas, menunjukkan bahwa nilai t-statistic untuk jumlah pegawai adalah -1,069 dan t-statistik untuk market kapitalisasi adalah 0,417. Nilai t-statistik tersebut lebih besar dari t-tabel dengan alpha $5 \%$ yaitu sebesar $-1,99$ dan lebih kecil dari 1,99. Sedangkan bila dilihat dari probabilitasnya, nilai signifikansi jumlah pegawai sebesar 0,288 dan signifikansi market kapitalisasi sebesar 0,678 , nilai ini lebih besar dari nilai alpha 0,05 .

Pada tabel analisis regresi diatas, tampak bahwa nilai t-statistic untuk kepemilikan adalah $-1,532$. Nilai t-statistik tersebut lebih besar dari t-tabel dengan alpha 5\% yaitu sebesar -1,99. Dan dari probabilitasnya, nilai signifikansi kepemilikan pada tabel diatas adalah 0,129, nilai ini lebih besar dari nilai alpha 0,05.

\section{Terjadi Underprice pada IPO Saham Perdana di BEJ}

Dari paparan diatas nampak bahwa rata-rata underprice yang terjadi pada IPO saham di BEJ adalah signifikan, signifikansi yang dimaksud adalah bahwa abnormal return tersebut secara statistik signifikan lebih besar dari nol dan positif yang mengindikasikan terjadinya underprice saham.

Sedangkan perhitungan statistik tingkat taraf nyata $(\alpha)$ sebesar 0,05 dengan derajat kebebasan (degree of freedom) sebesar n-1. Uji t (student-t test) menunjukkan hasil sebesar 6.3224 dan t-tabel sebesar 1,99 (one tail). Oleh karena itu abnormal return bersifat signifikan mengingat $\mathrm{t}$ hitung $>\mathrm{t}$ tabel (one tail). Dengan demikian Hipotesa H1 diterima.

\section{Pengaruh Reputasi Underwriter (UW)}

Dari dua perhitungan tabel analisis regresi diatas nampak bahwa t hitung 1,221 lebih kecil dari t tabel 1,99 dan signifikansi 0,226 lebih besar dari 0,05 artinya hipotesis $\mathrm{H} 2$ diterima. Artinya underwriter yang memiliki nama baik akan menyebabkan makin tingginya underprice saham saat IPO. Hal ini sejalan dengan penelitianpenelitian yang dilakukan sebelumnya, misalnya pada Carter (1987) dan penelitian di Indonesia seperti pada Dalyono (2000).

\section{Pengaruh Harga penawaran saham (offering price) terhadap underprice saham}

Dari perhitungan tabel regresi diatas nampak bahwa t hitung -3,663 lebih kecil dari $t$ tabel $-1,99$ dan signifikansi 0 lebih kecil dari 0,05 sehingga hipotesis H3 ditolak. Artinya harga penawaran saham IPO tidak memiliki pengaruh positif pada underprice saham saat IPO. Hal ini sejalan dengan penelitian-penelitian yang dilakukan sebelumnya, misalnya pada Tinic (1988), Osborne (1969) dan Fernandez (1993).

\section{Pengaruh Usia Operasional perusahaan terhadap underprice saham}

Dari perhitungan statistik diatas nampak bahwa thitung -1,631 lebih besar dari t tabel -1,99 dan signifikansi 0,107 lebih besar dari 0,05 sehingga hipotesis H4 diterima. Artinya Usia perusahaan berpengaruh pada underprice saham perdana saat IPO. Sejalan dengan penelitian-penelitian yang dilakukan sebelumnya, misalnya pada Carter 
(1987), Barry\& Brown (1985) dan Trisnawati (1998).

\section{Pengaruh Kategori Industri terhadap underprice saham}

Dari perhitungan statistik diatas nampak bahwa t hitung sebesar 1,429 lebih kecil dari $t$ tabel sebesar 1,99 dan signifikansi sebesar 0,157 lebih besar dari 0,05 maka hipotesis H5 diterima. Artinya Kategori industri memiliki pengaruh positif pada underprice saham perdana saat IPO. Sejalan dengan penelitian-penelitian yang dilakukan sebelumnya, misalnya pada Ritter (1984) dan Fernandez 1993.

\section{Pengaruh Tahun IPO terhadap underprice saham}

Perhitungan dipaparkan diatas nampak bahwa t hitung 1,366 lebih kecil dari t tabel 1,99 dan signifikansi sebesar 0,176 lebih besar dari 0,05 mengindikasikan bahwa hipotesis H6 diterima. Artinya Tahun pelaksanaan IPO memiliki pengaruh positif pada underprice saham perdana saat IPO.

\section{Size Company terhadap underprice saham}

Dari perhitungan diatas $t$ hitung keduanya masih diantara -1,99 dan 1,99 dan signifikansi keduanya lebih besar dari 0,05 maka hipotesis H7 diterima. Artinya Size perusahaan memiliki pengaruh positif pada underprice saham perdana saat IPO. Hal ini tidak sejalan dengan penelitian-penelitian yang dilakukan sebelumnya, misalnya Fernandez 1993.

\section{Kepemilikan perusahaan terhadap underprice saham}

Perhitungan statistik diatas mengindikasikan bahwa t hitung sebesar -1,532 lebih besar dari -1,99 dan signifikasni sebesar 0,129 lebih besar dari 0,05 sehingga hipotesis H8 diterima. Artinya Kepemilikan perusahaan memiliki pengaruh positif pada underprice saham perdana saat IPO.

\section{Analisis Hasil Penelitian}

Dari penelitian diatas, terdapat variabel yaitu harga penawaran yang dianggap berpengaruh terbalik terhadap underprice saham di BEJ. Pada harga penawaran yang murah, ternyata menghasilkan underprice yang tinggi, sedangkan harga penawaran yang tinggi menghasilkan underprice yang rendah. Hal ini disebabkan karena harga penawaran yang murah sering dianggap sebagai sinyal perusahaan yang dalam menjalankan bisnisnya mengandung resiko kecil. Sehingga harga penawaran saham yang murah akan membuat investor semakin berminat membeli saham mereka. Penelitian in membuktikan bahwa makin murah harga saham perdana maka makin besar kemungkinannya menghasilkan underprice.

Selain harga penawaran, variabel industri dianggap memiliki pengaruh positif pada underprice di BEJ. Artinya, industri non keuangan menghasilkan underprice lebih tinggi dari industri keuangan. Kondisi ini diperkirakan dipicu dengan kondisi industri di Indonesia yang setelah krisis tahun 1997, banyak industri keuangan di Indonesia yang dibenahi dengan penutupan beberapa bank yang tidak layak beroperasi. Nampaknya penutupan beberapa perusahaan bidang keuangan menurunkan minat investor membeli saham keuangan dibanding dengan membeli saham non keuangan yang dianggap lebih rendah resiko. Penelitian ini menunjukkan saham perusahaan non keuangan lebih berpotensi menghasilkan underprice di BEJ.

Dari variabel-variabel yang diuji tersebut, terdapat variabel yang hasil penelitiannya tidak sejalan dengan penelitian-penelitian sebelumnya yaitu size company terutama pada market kapitalisasi. Pada penelitian ini, market kapitalisasi berpengaruh pada terjadinya underprice saham di BEJ. Hal ini disebabkan makin besar jumlah kapitalisasi dianggap sebagai tindakan yang menjanjikan para investor. Perusahaan yang menerbitkan saham dalam kapitalisasi besar dianggap memiliki rencana bisnis yang baik untuk dijalankan, sehingga semakin besar market kapitalisasi suatu perusahaan pada saat IPO maka makin diminati oleh investor.

\section{Uji R-Square ( $\left.\mathbf{R}^{2}\right)$}

Uji R-Square atau $\mathrm{R}^{2}$, dilakukan untuk menguji seberapa besar kemampuan semua variabel independen dalam model yang digunakan dapat menerangkan perilaku variabel dependen.

Tabel 5. Hasil Perhitungan Uji R-Square $\left(\mathrm{R}^{2}\right)$ Model Summary

\begin{tabular}{ccccc}
\hline Model & $\mathrm{R}$ & $\mathrm{R}$ Square & $\begin{array}{c}\text { Adjusted R } \\
\text { Square }\end{array}$ & $\begin{array}{c}\text { Std. Error of the } \\
\text { Estimate }\end{array}$ \\
\hline 1 & 0,739 & 0,546 & 0,502 & 0,9561758 \\
\hline a Predictors: (Constant), MCAP, OWNER, INDUSTRI, YEAR, AGE, EMPLOYEE, UW, OFPRICE
\end{tabular}


Tampak bahwa dari perhitungan analisis regresi yang dilakukan nilai R-Square yang diperoleh adalah sebesar 0,546 atau 54,6\%. Artinya bahwa variabel-variabel independen dalam model regresi mampu menerangkan $54,6 \%$ pada underprice saham saat IPO, dan sisanya sebesar 45,4\% diterangkan oleh variabel-variabel lain diluar model regresi diatas.

Tabel 6. Hasil Perhitungan Uji Nilai F (F-test)

\begin{tabular}{|c|c|c|c|c|c|c|}
\hline Model & & $\begin{array}{l}\text { Sum of } \\
\text { Squares }\end{array}$ & $\mathrm{df}$ & $\begin{array}{l}\text { Mean } \\
\text { Square }\end{array}$ & F & Sig. \\
\hline \multirow[t]{3}{*}{1} & Regression & 91,291 & 8 & 11,411 & 12,481 & 0,000 \\
\hline & Residual & 75,885 & 83 & 0,914 & & \\
\hline & Total & 167,176 & 91 & & & \\
\hline
\end{tabular}

Pengujian nilai $\mathrm{F}$ atau F-test ini dipergunakan untuk mengetahui signifikansi dari semua koefisien regresi secara bersama-sama. Nilai hasil perhitungan regresi menunjukkan bahwa didapat $\mathrm{F}$ hitung sebesar 12,481 dengan tingkat signifikansi sebesar 0,000 . Oleh karena tingkat probabilitas 0,000 lebih kecil dari 0,05, maka model regresi dapat digunakan untuk memprediksi variabel dependen underprice saham.

Dengan demikian dapat dinyatakan dengan kata lain bahwa secara statistik, variabel-variabel independen dalam model regresi penelitian secara bersama-sama berpengaruh terhadap underprice saham IPO.

Tabel 7. Hasil Perhitungan Uji Multikolinearitas.

\begin{tabular}{|c|c|c|c|c|c|c|c|c|c|}
\hline & UND & INDUSTRI & AGE & EMPLOYEE & OWNER & UW & YEAR & OFPRICE & MCAP \\
\hline UND & 1,000 & & & & & & & & \\
\hline INDUSTRI & 0,155 & 1,000 & & & & & & & \\
\hline AGE & $-0,456$ & $-0,289$ & 1,000 & & & & & & \\
\hline EMPLOYEE & $-0,401$ & 0,147 & 0,310 & 1,000 & & & & & \\
\hline OWNER & 0,050 & $-0,031$ & $-0,151$ & $-0,131$ & 1,000 & & & & \\
\hline UW & $-0,265$ & $-0,141$ & 0,296 & 0,420 & 0,058 & 1,000 & & & \\
\hline YEAR & 0,573 & $-0,064$ & $-0,272$ & $-0,409$ & 0,202 & $-0,371$ & 1,000 & & \\
\hline OFPRICE & $-0,703$ & $-0,069$ & 0,486 & 0,534 & $-0,187$ & 0,429 & $-0,780$ & 1,000 & \\
\hline MCAP & $-0,195$ & $-0,127$ & 0,165 & 0,369 & $-0,031$ & 0,475 & $-0,265$ & 0,322 & 1,000 \\
\hline
\end{tabular}

Multikolinearitas merupakan keadaan dimana terdapat hubungan linier yang sempurna atau mendekati sempurna antara berapa atau seluruh variabel independen (Kuncoro, 2001). Apabila terdapat korelasi antara dua variabel independen lebih tinggi dari pada korelasi salah satu variabel independen tersebut dengan variabel dependennya, maka hal tersebut merupakan gejala adanya multikolinearitas.

Multikolinearitas ini merupakan masalah yang serius apabila korelasi antara dua variabel bebas lebih besar dari 0,8 (Gujarati, 1995). Berdasarkan matrik diatas, terlihat bahwa korelasi antara delapan variabel cukup bervariasi. Meskipun terdapat variabel independen yang saling berhubungan lebih besar dari hubungan dengan variabel dependennya, yaitu tahun IPO terhadap harga penawaran, namun angka tersebut masih lebih kecil dari 0,8 , sehingga tidak terdapat multikolinearitas yang serius. 


\section{KESIMPULAN}

Berdasarkan uji t student (t-test) terhadap return tidak normal pada penjualan saham perdana, diperoleh hasil bahwa abnormal return adalah positif. Hal ini dapat disimpulkan bahwa fenomena underprice memang terjadi pada IPO di BEJ.

Berdasarkan hasil pengujian multiple linier regression method, diperoleh kesimpulan bahwa sebagian besar variabel-variabel independen yaitu prestige underwriter, tahun IPO, kategori Industri, Usia operasional, jumlah pegawai, market kapitalisasi dan kepemilikan berpengaruh kepada underprice saham perdana, terutama variabel kategori industri yang memiliki pengaruh positif dan harga penawaran yang memberi pengaruh negatif pada underprice saat IPO di BEJ.

Beberapa keterbatasan antara lain, tidak terdapatnya data sales perusahaan pada prospektus secara konstan (tidak semua perusahaan mencantumkan sales mereka), sehingga penulis tidak mencantumkan sales sebagai salah satu variabel independen dalam penelitian ini.

Pada periode penelitian, yaitu 1995 hingga 2001, terjadi krisis ekonomi yang cukup berat yang dialami Indonesia dan memungkinkan terjadinya perubahan perilaku investasi pada saat itu.

\section{DAFTAR PUSTAKA}

Block, S. \& M. Stanley. 1980. "The Financial Characteristics and Price Movement Patterns of Companies Approaching the Unseasoned Securities Market in the Late 1970s.” Financial Management: 30-36.

Brigham, Eugene F., 1999, Gapensi, Louis C. and Davis, Philip R., Intermadiate Finance Management, Sixth Edition, The Dry Press Harcourt Brace College Publisher, New York.

Brown, J. M. 1970. “Post-Offering Experience of Companies Going Public.” Journal of Business: 10-18.

Carter, R. B. 1987. "Initial Public Offerings and the Underwriter Signal.” Doctoral dissertation, University of Utah.

Daljono, 2000, “Analisis Faktor-Faktor yang Mempengaruhi Initial Return Saham yang Listing di BEJ Tahun 1990-1997”, Kumpulan Makalah Simposium Nasional Akuntansi III, pp. 556-572.

Fernandez, Martinez, Rahnema 1993. "Initial Public Offering (IPOs) The Spanish Experience.” Research Paper $\mathrm{N}^{\circ}$ 243, IESE, Universidad de Navarra, Barcelona.

Firth, Michael, and Tan, Chee Keng Liau, 1997, "Signaling Models and The Valuation of new issues: Examination of IPOs in Singapore”, Pacific-Basin Finance Journal, Vol. 5, No. 5, December, pp. 511-526.

Hartono, Jogiyanto, 2000, Teori Portofolio dan Analisis Investasi, Edisi Kedua, BPFE, Yogyakarta.

Husnan, Suad, 2001, Dasar-Dasar Teori Portofolio dan Analisis Sekuritas, Edisi Ketiga, Cetakan Kedua, UPPAMP YKPN, Yogyakarta.

Ibbotson, R. G. \& 1. J. Jaffe. 1975. "Hot Issue Markets.” Journal of Finance 30: 1027-1042.

Jakarta Stock Exchange (JSX), Indonesian Capital Market Directory, 1998-2001.

Jakarta Stock Exchange (JSX), Statistics, 1998-2001.

Logue, D. E. 1973. “On the Price of Unseasoned New Issues, 1965-1969.” Journal of Finance and Quantitative Analysis": 91-103.

McDonald, J.G. \& A. K. Fischer. 1972. “New-Issue Stock Price Behavior.” Journal of Finance 27: 97-102.

Miller, R. E. \& F. K. Reilly. 1987. "An examination of Mispricing, Returns and Uncertainty for Initial Public Offerings.” Financial Management: 33-38.

Muscarella, C. J. \& M. R. Vetsuypens. 1987. "Initial Public Offerings and Information Asymmetry.” Unpublished, Edwin L. Cox School of Business, Southern Methodist University.

Osborne, M. F. M. 1969:”'Periodic Structure in the Brownian Motion of Stock Prices.” In P. H. Cootner, ed. The 
Random Character of Stock Market Prices. Cambridge, Massachusetts: MIT Press.

Ritter, J. 1984. “The 'Hot Issue' Market.” Journal of Business 57: 215-240.

Rock, K. 1986. “Why New Issues are Underpriced.” Journal of Financial Economics 15: 187-212.

Santoso, Singgih, 2001, SPSS Versi 10 Mengolah Data Secara Profesional, PT. Elex Media Komputindo, Kelompok Gramedia, Jakarta.

Santoso, Singgih, 2001, Riset Pemasaran Konsep dan Aplikasi dengan SPSS, PT. Elex Media Komputindo, Kelompok Gramedia, Jakarta.

Tinic, S. M. 1988. “Anatomy of Initial Public Offers of Common Stock.” Journal of Finance 43: 789-822.

Trisnawati, Rina, 1998, "Pengaruh Informasi Prospektus Terhadap Return Saham di Pasar Perdana”, Tesis S2 UGM, tidak dipublikasikan.

\section{LAMPIRAN}

Lampiran 1. Tabel Data Hasil Perhitungan Harga Saham Underprice

\begin{tabular}{cllcccc}
\hline No. & Perusahaan & $\begin{array}{c}\text { Kode } \\
\text { Saham }\end{array}$ & $\begin{array}{c}\text { Hrg } \\
\text { Perdana } \\
(\mathbf{R p})\end{array}$ & $\begin{array}{c}\text { Hrg } \\
\text { Penutupan } \\
\text { Hari } \mathbf{1} \\
(\mathbf{R p})\end{array}$ & $\begin{array}{c}\text { Selisih } \\
\text { / Initial } \\
\text { Return }\end{array}$ & Underprice \\
\hline 1 & PaninOverseasFinance & POFI & 1300 & 1125 & -175 & -0.1346 \\
\hline 2 & SinarMasMultiartha & SMMA & 1800 & 1950 & 150 & 0.0833 \\
\hline 3 & BudiAcidJaya & BUDI & 3000 & 3000 & 0 & 0 \\
\hline 4 & SuryaHidupSatwa & SHSA & 1125 & 1175 & 50 & 0.0444 \\
\hline 5 & AsahimasFlatGlassCo.Ltd & AMFG & 2450 & 2475 & 25 & 0.0102 \\
\hline 6 & SuryaMasDutaMakmur & SMDM & 850 & 750 & -100 & -0.1176 \\
\hline 7 & TelkomIndonesia & TLKM & 2050 & 2100 & 50 & 0.0244 \\
\hline 8 & TunasRidean & TURI & 2700 & 2750 & 50 & 0.0185 \\
\hline 9 & BimantaraCitra & BMTR & 1250 & 1800 & 550 & 0.44 \\
\hline 10 & TambangTimah & TINS & 2900 & 2925 & 25 & 0.0086 \\
\hline 11 & PerdanaBangunPusaka & KONI & 950 & 900 & -50 & -0.0526 \\
\hline 12 & MustikaRatu & MRAT & 2600 & 3000 & 400 & 0.1538 \\
\hline 13 & ElangRealty & ELTY & 625 & 625 & 0 & 0 \\
\hline 14 & KomatsuIndonesia & KOMI & 2100 & 2000 & -100 & -0.0476 \\
\hline 15 & MiwonIndonesia & MWON & 1950 & 1450 & -500 & -0.2564 \\
\hline 16 & P.P. LondonSumatraindonesia & LSIP & 4650 & 4750 & 100 & 0.0215 \\
\hline 17 & SelamatSempurna & SMSM & 1700 & 1850 & 150 & 0.0882 \\
\hline 18 & RamayanaLestariSentosa & RALS & 3200 & 3675 & 475 & 0.1484 \\
\hline 19 & SiantarTop & STTP & 2200 & 2350 & 150 & 0.0682 \\
\hline 20 & PelangiIndahKanindo & PICO & 650 & 725 & 75 & 0.1154 \\
\hline 21 & TriPolytaIndonesia & TPIA & 2575 & 2575 & 0 & 0 \\
\hline 22 & BankBNI & BBNI & 850 & 1250 & 400 & 0.4706 \\
\hline 23 & CahayaKalbar & CEKA & 1100 & 1175 & 75 & 0.0682 \\
\hline 24 & CitatahIndustriMarmer & CTTH & 2375 & 2500 & 125 & 0.0526 \\
\hline 25 & SuryaDumaiIndustri & SUDI & 1000 & 1075 & 75 & 0.075 \\
\hline 26 & SieradProduce & SIPD & 900 & 825 & -75 & -0.0833 \\
\hline 27 & LippoKarawaci & LPKR & 3250 & 3500 & 250 & 0.0769 \\
\hline 28 & KedaungSetiaIndustrial & KDSI & 800 & 825 & 25 & 0.0313 \\
\hline 29 & AlumindoLightMetalIndustry & ALMI & 1300 & 1400 & 100 & 0.0769 \\
\hline 30 & BankPikko & BNPK & 800 & 900 & 100 & 0.125 \\
\hline 31 & AlterAbadi & ALDI & 900 & 1025 & 125 & 0.1389 \\
\hline & & & & & & \\
\hline & & & & \\
\hline
\end{tabular}




\begin{tabular}{|c|c|c|c|c|c|c|}
\hline 32 & AstraOtoparts & AUTO & 575 & 500 & -75 & -0.1304 \\
\hline 33 & SURYAINTIPERMATA & SIIP & 600 & 1225 & 625 & 1 \\
\hline 34 & JakartaSetiabudiProperty & JSPT & 900 & 700 & -200 & -0.2222 \\
\hline 35 & BaligrahaMedikatama & BGMT & 500 & 550 & 50 & 0.1 \\
\hline 36 & MAKINDO & MKDO & 975 & 1125 & 150 & 0.1538 \\
\hline 37 & RICKYPUTRAGLOBALINDO & RICY & 600 & 650 & 50 & 0.0833 \\
\hline 38 & BankDanpac & BDPC & 500 & 575 & 75 & 0.15 \\
\hline 39 & BahteraAdiminaSamudera & BASS & 625 & 750 & 125 & 0.2 \\
\hline 40 & TirtaMahakamPlywoodIndustry & TIRT & 875 & 975 & 100 & 0.1143 \\
\hline 41 & CiptojayaKontrindoreksa & CKRA & 250 & 400 & 150 & 0.6 \\
\hline 42 & BintangMitraSemestaraya & BMSR & 500 & 1100 & 600 & 1.2 \\
\hline 43 & BankVictoriaInternational & BVIC & 100 & 200 & 100 & 1 \\
\hline 44 & AdindoForestaIndonesia & $\mathrm{ADFO}$ & 500 & 925 & 425 & 0.85 \\
\hline 45 & ManlyUnitamaFinance & MANY & 500 & 1025 & 525 & 1.05 \\
\hline 46 & AndhiChandraAutomotiveProduct & ACAP & 875 & 1325 & 450 & 0.5143 \\
\hline 47 & GowaMakassarTourismDev & GMTD & 575 & 1050 & 475 & 0.8261 \\
\hline 48 & BankArthaNiagaKencana & ANKB & 500 & 550 & 50 & 0.1 \\
\hline 49 & DyviaComIntrabumi & DNET & 250 & 295 & 45 & 0.18 \\
\hline 50 & TempoIntiMedia & TMPO & 300 & 495 & 195 & 0.65 \\
\hline 51 & RimoCaturLestari & RIMO & 500 & 475 & -25 & -0.05 \\
\hline 52 & TunasBaruLampung & TBLA & 2200 & 2400 & 200 & 0.0909 \\
\hline 53 & BankMega & MEGA & 1200 & 1200 & 0 & 0 \\
\hline 54 & AlfaRetailindo & ALFA & 550 & 1100 & 550 & 1 \\
\hline 55 & SummitplastInterbenua & SMPL & 800 & 1010 & 210 & 0.2625 \\
\hline 56 & FortuneMateIndonesia & FMII & 500 & 825 & 325 & 0.65 \\
\hline 57 & DharmaSamudraFishingIndustry & DSFI & 900 & 1150 & 250 & 0.2778 \\
\hline 58 & AsiaplastIndustries & APLI & 600 & 1100 & 500 & 0.8333 \\
\hline 59 & SuryaIntrindoMakmur & SIMM & 500 & 975 & 475 & 0.95 \\
\hline 60 & BankBuanaIndonesia & BBIA & 700 & 825 & 125 & 0.1786 \\
\hline 61 & KridaPerdanaIndahGraha & KPIG & 500 & 1450 & 950 & 1.9 \\
\hline 62 & TrimegahSecurities & TRIM & 2000 & 5300 & 3300 & 1.65 \\
\hline 63 & BankCentralAsia & BBCA & 1400 & 1400 & 0 & 0 \\
\hline 64 & PaninSekuritas & PANS & 550 & 700 & 150 & 0.2727 \\
\hline 65 & INDOFARMA & INAF & 100 & 230 & 130 & 1.3 \\
\hline 66 & KOPITIMEDOTCOM & KOPI & 250 & 300 & 50 & 0.2 \\
\hline 67 & PANORAMASENTRAWISATA & PANR & 500 & 625 & 125 & 0.25 \\
\hline 68 & TEMPOINTIMEDIA & TMPO & 100 & 495 & 395 & 3.95 \\
\hline 69 & BANKNUSANTARAPARAHYANGAN & BBNP & 500 & 550 & 50 & 0.1 \\
\hline 70 & ARGHAKARYAPRIMAINDS. & AKSI & 100 & 260 & 160 & 1.6 \\
\hline 71 & BANKEKSEKUTIFINTERNASIONALT & BEKS & 100 & 195 & 95 & 0.95 \\
\hline 72 & PYRIDAMFARMA & PYFA & 100 & 200 & 100 & 1 \\
\hline 73 & DAEYUORCHIDINDONESIA & DOID & 100 & 150 & 50 & 0.5 \\
\hline 74 & PLASTPACKPRIMAINDUSTRI & PLAS & 100 & 510 & 410 & 4.1 \\
\hline 75 & INFOASIATEKNOLOGIGLOBAL & IATG & 100 & 440 & 340 & 3.4 \\
\hline 76 & INDOEXCHANGEDOTCOM & INDX & 25 & 115 & 90 & 3.6 \\
\hline 77 & ARWANACITRAMULIA & ARNA & 100 & 140 & 40 & 0.4 \\
\hline 78 & LAPINDOPACKAGING & LAPD & 100 & 450 & 350 & 3.5 \\
\hline 79 & RYANEADIBUSANA & RYAN & 100 & 580 & 480 & 4.8 \\
\hline 80 & BETONJAYAMANUNGGAL & BTON & 100 & 315 & 215 & 2.15 \\
\hline 81 & LAMICITRANUSANTARA & LAMI & 125 & 240 & 115 & 0.92 \\
\hline 82 & METAMEDIATECHNOLOGIES & META & 100 & 235 & 135 & 1.35 \\
\hline 83 & KARKAYASAPROFILIA & KARK & 100 & 110 & 10 & 0.1 \\
\hline 84 & AKBARINDOMAKMURSTIMEC & AIMS & 100 & 730 & 630 & 6.3 \\
\hline 85 & RODAPANGGONHARAPAN. & RODA & 100 & 445 & 345 & 3.45 \\
\hline
\end{tabular}




\begin{tabular}{cllcccc}
\hline 86 & INDOSIARVISUAL & IDSR & 250 & 675 & 425 & 1.7 \\
\hline 87 & CENTRALKORPORINDOINTL & CNKO & 100 & 220 & 120 & 1.2 \\
\hline 88 & WAHANAPHONIXMANDIRI & WAPO & 100 & 505 & 405 & 4.05 \\
\hline 89 & INTEGRASITEKNOLOGI & ITTG & 25 & 105 & 80 & 3.2 \\
\hline 90 & LIMASSTOKHOMINDO & LMAS & 100 & 510 & 410 & 4.1 \\
\hline 91 & COLORPAKINDONESIA & CLPI & 100 & 410 & 310 & 3.1 \\
\hline 92 & CENTRINONLINE. & CENT & 100 & 380 & 280 & 2.8 \\
\hline
\end{tabular}

